\title{
Ban on Designating Plant Products as Dairy: Between Market Regulation and Over-Protection of the Consumer
}

\author{
Daniele PISANELLO* and Luchino FERRARIS**
}

Case C-422/16, Verband Sozialer Wettbewerb eV v TofuTown.com GmbH, ECLI:EU: $C: 2017: 458$

In the decision relating to Case $\mathrm{C}-422 / 16$, Verband Sozialer Wettbewerb eV v TofuTown.com GmbH, the European Court of Justice set a limit on the practice of using the terms "milk" or "dairy" to designate products which are purely plantbased. This article will explore the reasoning underlying this decision and will focus on some possible criticisms. In fact, although potentially innovative, this decision falls short of dealing with repercussions regarding the discipline of consumer protection.

\section{INTRODUCTION}

On 14 June 2017, the European Court of Justice delivered its final ruling in Case C-422/ 16 (hereinafter "TofuTown"). ${ }^{1}$ In doing so, the ECJ called a halt to the long-lasting controversy regarding designations such as "soy milk", "tofu", "veggie milk" and so forth, used for products that are not animal-based. The legislation in force ${ }^{2}-$ the Court asserts - "must be interpreted as precluding the term 'milk' and the designations reserved by that regulation exclusively for milk products from being used to designate a purely plant-based product in marketing or advertising, even if those terms are expanded upon by clarifying or descriptive terms indicating the plant origin of the product at issue". 3 Exception can be made to this rule only if explicitly stated by the Commission. ${ }^{4}$

This ban, even in the presence of other descriptive information which appears in proximity to the "name" of the food, ${ }^{5}$ as will be seen, is considered by the Court to be entirely matter of

\footnotetext{
* Food Lawyer and Managing Partner at LEX Alimentaria, Italy - pisanello@ lexalimentaria.eu.

** Sant'Anna School of Advanced Studies, Pisa - l.ferraris@ santannapisa.it.

1 Case C-422/16, Verband Sozialer Wettbewerb eV v TofuTown.com GmbH (TofuTown) [2017].

2 Art 78(2) and Annex VII, Part III, to European Parliament and Council Regulation (EU) 1308/2013 establishing a common organisation of the markets in agricultural products and repealing Council Regulations (EEC) 922/72, (EEC) 234/79, (EC) 1037/2001 and (EC) 1234/2007.

TofuTown, supra note 1, para. 53.

4 The product must be listed in Annex I to Commission Decision 2010/791/EU listing the products referred to in the second subparagraph of point III(1) of Annex XII to Council Regulation (EC) 1234/2007.

5 The discipline of the "name" of the food is laid down in Art 17, para. 2 European Parliament and Council Regulation (EU) 1169/2011 on the provision of food information to consumers.
} 
market regulation. There is no consideration, however, regarding its repercussions on consumer protection, which on the contrary, it would have been wiser to take into account. In fact, with extension of the above-mentioned ban even to the hypothesis in which there is no likelihood of confusion, the Court effectively outlines an excessive protection of the consumer, ie even if his or her rights to be informed are not impaired.

\section{FACTS AND QUESTIONS REFERRED FOR A PRELIMINARY RULING}

The dispute in the main proceedings may be summarised as follows. The Verband Sozialer Wettbewerb ("VSW") is a German association opposed, inter alia, to unfair competition. TofuTown is a company which produces and distributes vegetarian/vegan foodstuffs. It promotes and distributes, among other items, pure plant-based products.

VSW sued Tofutown - also requesting the application of provisional measures ${ }^{6}-$ arguing that the promotion by TofuTown of the pure plant-based products, particularly under the designations "Soyatoo tofu butter", "Plant cheese", "Veggie Cheese", "Cream" and other similar designations, infringes competition rules. Indeed, the issue had already been settled in a previous judgement, in which the ECJ held that Regulation (EC) 1898/87 precluded the use of the description "cheese" for products in which the milk fat has been replaced by vegetable fat, even if that description is complemented by additional descriptive material. ${ }^{7}$ Notwithstanding this, the national Court still felt unsure as to the interpretation of Article 78 of Regulation No 1308/2013 in conjunction with Annex VII, Part III, points 1 and 2, thereof, for the purpose of deciding the dispute before it. ${ }^{8}$ The national Court thus referred three questions to the Court of Justice for a preliminary ruling, which can indeed be encapsulated in one: does EU law in force allow designations relating to "milk" products for products that are, in essence, plant-based, even in the presence of other descriptive information (such as "tofu") which clarifies and indicates the "name" of the food? Against this background, a more general problem is posed.

\footnotetext{
6 The action was brought before the Landgericht Trier (Regional Court, Trier, Germany), relying on an infringement of para 3a of the Law on Unfair Competition, in conjunction with Annex VII, Part III, points 1 and 2, and Art 78 of Regulation No 1308/2013. The German Law against Unfair Competition, in the version applicable to the dispute in the main proceedings, provides in para 3a: "A person who infringes a statutory provision that is also intended to regulate market behaviour in the interests of market participants shall be regarded as acting unfairly [where] the infringement is liable to have a perceptible adverse effect on the interests of consumers, other market participants or competitors".

7 Case C-101/98, Union Deutsche Lebensmittelwerke GmbH v Schutzverband gegen Unwesen in der Wirtschaft eV. (UDL) [1999] ECR I-08841.

8 Art 78 of Regulation No 1308/2013, entitled "Definitions, designations and sales descriptions for certain sectors and products", provides:

"1. In addition, where relevant, to the applicable marketing standards, the definitions, designations and sales descriptions provided for in Annex VII shall apply to the following sectors or products:

[...]

(c) milk and milk products intended for human consumption;

[...]

2. The definitions, designations or sales descriptions provided for in Annex VII may be used in the Union only for the marketing of a product which conforms to the corresponding requirements laid down in that Annex.

3. The Commission shall be empowered to adopt delegated acts ... concerning the modifications, derogations or exemptions to the definitions and sales descriptions provided for in Annex VII. Those delegated acts shall be strictly limited to demonstrated needs resulting from evolving consumer demand, technical progress or the need for product innovation.

$[\ldots]$

5. In order to take into account the expectations of consumers and the evolution of the milk products market, the Commission shall be empowered to adopt delegated acts [...] to specify the milk products in respect of which the animal species from which the milk originates is to be stated, if it is not bovine, and to lay down the necessary rules".
} 
This concerns the influence that the "vegan mantra" may exert on the consumers. In fact, the designation "no animal" may constitute an appealing market alternative for the general public.

\section{THE COURT'S DECISION}

The reasoning of the ECJ is very careful about being in line with the exact wording of the text of the legislation involved. In fact, as seen above, the Court is explicit in prohibiting that designations relating to "milk" products are used for plant-based products, though with the exceptions already mentioned. This continues to be true even when adequate descriptive information is specified. ${ }^{9}$ In so doing, the Court draws most of the reasoning from the 18-year-younger $U D L$ case, ${ }^{10}$ apart from the obiter dicta stated to overcome TofuTown's arguments on the purported violations of the principle of proportionality and the principle of non-discrimination.

As regards the principle of proportionality, it is easy for the Court to rule that in matters concerning the Common Agricultural Policy the EU legislature has a broad discretion coming from Articles 40 and 43 TFEU. Thus, a measure can be dismissed only if manifestly inappropriate, having regard for the objective which the competent institution is seeking to pursue. ${ }^{11}$ As far as common organisation of agricultural markets is concerned, such objectives "consist, in particular, in improving the economic conditions for the production and marketing as well as the quality of such products. The application of such standards is therefore in the interest of producers, traders and consumers, to protect consumers and to maintain conditions for allowing competition". ${ }^{12}$ This - according to the Court - justifies the existence of the ban even in the presence of adequate descriptive information in labelling or any other means of communication. Therefore, the Court makes it clear that the rules in question shall be interpreted so as to serve the legislature's aims. The latter are to ensure the requirements "to the producers of those products" (author's note: dairy producers) "of undistorted conditions for competition, and to consumers of those products, that the products designated by those designations meet all the same standards of quality, both protecting them against any confusion as to the composition of the products they intend to purchase". ${ }^{13}$ The exception of proportionality can therefore be considered as dismissed on condition that the limits of what is appropriate and necessary in order to attain the objectives legitimately pursued by the legislation in question are not exceeded. In fact, "the addition of descriptions or explanations to those designations to designate products which do not satisfy those requirements cannot prevent with certainty any likelihood of confusion in the mind of the consumer". ${ }^{14}$

With regard to the principle of non-discrimination, the matter was raised with reference to the equal treatment between producers of vegetarian or vegan substitutes for milk or milk products and those of vegetarian or vegan substitutes for meat or fish. In fact, according to TofuTown, the latter are not subject to restrictions comparable to those of the

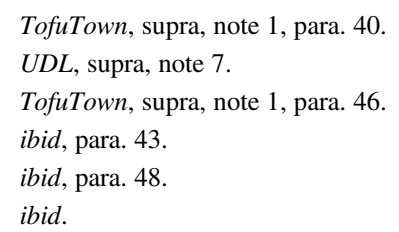


former in terms of sales description. On this point, the Court affirms that the principle requires comparable situations not to be treated differently and different situations not to be treated alike unless such treatment is objectively justified. ${ }^{15}$ Against this background, it can be said that "each sector of the common organisation of markets for agricultural products established by that regulation embodies features specific to it. As a result, a comparison of the technical rules and procedures adopted in order to regulate the various sectors of the market cannot constitute a valid basis for the purpose of proving the complaint of discrimination between dissimilar products which are subject to different rules". ${ }^{16}$

\section{AN EXCESSIVE PROTECTION OF THE CONSUMER?}

As mentioned above, the decision revolves around a literal interpretation of the provisions contained of the common organisation of agricultural matters. This stance is justified by the need to protect a particular type of food business operator (ie dairy producers), as well as having the aim of defending the consumer's rights.

The Court recognised a wide discretion to the EU legislature, which ensures that the ban is lawful despite the fact that it is only applicable to producers of one supply chain, whereas the others must continue to respect regular competition rules. On the contrary, the reference to consumer protection is used as an argument to justify the ban even where the addition of descriptions or explanations to those designations should avoid any possible likelihood of confusion in practice. Whereas the first argument is entirely in line with settled case law, the latter is indeed open to criticism. It is hard to believe that the Court stumbled into such a blatant contradiction. It is more credible that the reference was made to a different - and deeper - notion of "likelihood of confusion". It is, in other words, probable that what the Court referred to was the "likelihood of alteration of consumer perception", usually understood by reference to the timing of the purchase. Such an alteration may indeed refer to a deeper concept, which is susceptible to substantiate the real "fundamental architecture of mass communication". ${ }^{17}$ This is the only possible explanation to understand the reasoning of the Court, given that in the present case no plausible likelihood of confusion for the consumer could ever have occurred. In this regard, the argument of the Court is not at all plucked out of the air, especially if the (paternalistic) need to shield the consumer is related to a sort of silent shift of meaning of words and concepts which may deceive the consumer while purchasing. Having second thoughts, the Court had already expressed such a "mythopoeic" conception of the commercial offer. This is clear in the case Severi, where the ECJ asserts that "among the factors to be taken into account in order to assess whether the labelling at issue in the main proceedings may be misleading, the length of time for which a name has been used is an objective factor which might affect the expectations of the reasonable consumer". ${ }^{18}$

This is clearly one of the main axes of the decision. However, as long as the ban is only applicable in one supply chain, the impression remains that the protection offered to the consumer is given without having been asked for. In the best case scenario, such protection

15 ibid, para. 49, and case law referred to therein.

16 ibid, para. 51.

17 Ugo Volli, Semiotica della pubblicità (Laterza 2005) 138, 4.

18 C-446/07, Alberto Severi v Regione Emilia Romagna (Severi) [2009] ECR I-08041, para. 62. On this point, $c f$ D Pisanello, "Il consumer batte la legge: la Corte di giustizia sulla disputa salame Felino" (ItaliaOggi - 12 September 2009). 
is totally asymmetric, as it depends upon the supply chain concerned. Thus, the consumer is more protected in relation to dairy products than, for instance, in relation to meat and fish.

In sum, whereas the Court has sometimes prioritised teleological interpretations, ${ }^{19}$ this time it has clearly preferred to tie its reasoning to a literal one. The aim has plausibly been to issue a wide-ranging decision, so as to frame vegan communication within the more general discipline of food information.

The issue at stake is likely to come up again in the future, particularly as the Commission - the exclusive master of the right of initiative - has made it clear that regulation of the dairy sector on this point will not be exported to the meat sector. ${ }^{20}$

\section{VEGAN FOOD COMMUNICATION: A REGULATORY PROBLEM?}

It is worth noticing that the Court does not seize this opportunity to shed light on the relationship between the present case and the general discipline of food information to consumers laid down in Regulation (EU) 1169/2011. This leaves some questions unsolved regarding the consumption of vegan food. It is no coincidence that the Commission recently took an initiative to resolve the problem of defining "vegan" and "vegetarian" food at legislative level. ${ }^{21}$ In particular, the issue of the rapid rise of different designations for products such as "soy-burger", "vegan bresaola", "vegan mortadella" and so forth remains completely unexplored. ${ }^{22}$ An intervention on this point at EU level has been awaited since 2011 by virtue of Article 36, para 3, lett b), which provided that "the Commission shall adopt implementing acts on the application of the requirements referred to in paragraph 2 of this Article to [...] information related to suitability of a food for vegetarians or vegans". Because of the lack of any action by the Commission, an intervention of the Court in this respect would have perhaps been desirable to frame and unravel the main specificities of vegan communication. This ambit presents delicate issues, especially by virtue of the increasing usage of means of communications which - with a view to establishing a preferential relationship with the consumer - may affect competitors' rights, particularly in the case of comparative advertising.

In the context of food law, the additional descriptions, such as those used in the TofuTown case, are ascribable to so called "voluntary food information", mentioned in Chapter V of Regulation (EU) 1169/2011 and linked to the "fair information practices" mentioned in Article 7 of the same piece of legislation. The main rule concerning such information is that it shall not be "misleading". 23

\footnotetext{
19 One important example is Joined Cases C-503/13 and C-504/13, Boston Scientific Medizintechnik GmbH contro AOK Sachsen-Anhalt - Die Gesundheitskasse. On this decision, see the commentary of L Bergkamp, "Is There a Defect in the European Court's Defect Test?" (2015) 2 EJRR 309.

$20 C f$ the answer given by Mr Vytenis Andriukaitis on behalf of the Commission to Parliamentary question E-003771/ 2016: "The Commission considers that the applicable provisions provide sufficient legal basis to protect consumers from being misled".

21 See on this issue the contribution by FratiniVergano European Lawyers, 'Trade Perspectives', Issue 21 - 17 November 2017, available at <www.fratinivergano.eu/en/trade-perspectives/>.

22 For instance, in Poland language adjustments provoke the turning of "salami" into "salani", "mortadella" into "nortadella", "hamburger" into "damburger". On this point, $c f$ I Sirakova, "EU-Food Law after REFIT: Better Regulations or More of the Same” (2016) 6 European Food and Feed Law 531, 533.

23 The prohibition of misleading information to food consumers is recognised in the first paragraph of Art 7 and substantiated in four hypotheses cited therein, which should not be considered as a numerus clausus. In particular, food information shall not be misleading:

"(a) as to the characteristics of the food and, in particular, as to its nature, identity, properties, composition, quantity, durability, country of origin or place of provenance, method of manufacture or production;
} 
Moreover, it is perfectly possible for the "food business operator responsible for the food information" 24 to use regular designations relating to products of animal origin (such as hamburger, "bresaola", "eggs" or "salame") 25 in the labelling of products which are entirely vegan (or vegetarian). This would give rise to a proper proliferation of the name under which a product is sold, drawing on the so called "descriptive name". ${ }^{26}$

It is worth noticing that the freedom that the food business operator has to choose the name under which the product is sold - unless this is legally pre-determined ("legal name") - is relatively recent as it traces back to Directive 79/112/EEC. ${ }^{27}$ A "creative" role of the food business operator is therefore recognised, although with some limits. As a result, the name under which a product is sold is first and foremost the "legal name"; ${ }^{28}$ in its absence, its "customary name" or the "descriptive name". ${ }^{29}$ In the original text of Article 5 Directive 79/112/EEC - then integrated into Article 17 Regulation (EU) 1169/2011, "the name under which a foodstuff is sold shall be the name laid down by whatever laws, regulations or administrative provisions apply to the foodstuff in question or, in the absence of any such name, the name customary in the Member State where the product is sold to the ultimate consumer, or a description of the foodstuff and, if necessary, of its use, that is sufficiently precise to inform the purchaser of its true nature and to enable it to be distinguished from products with which it could be confused".

It may be affirmed that the limits to the use of the "descriptive name" are not due to its potential to deceive, which would - in case - be relevant under Article 7. On the contrary, such limits are aimed at enabling the consumer to identify the "true nature" of a product and to avoid confusion with other similar products. If this is the case - ie if there a likelihood of confusion - the benchmark is set by the ECJ as being "presumed

(F'note continued)

(b) by attributing to the food effects or properties which it does not possess;

(c) by suggesting that the food possesses special characteristics when in fact all similar foods possess such characteristics, in particular by specifically emphasising the presence or absence of certain ingredients and/or nutrients; (d) by suggesting, by means of the appearance, the description or pictorial representations, the presence of a particular food or an ingredient, while in reality a component naturally present or an ingredient normally used in that food has been substituted with a different component or a different ingredient".

24 On this notion, see D Pisanello, 'Le responsabilità per la conformità della fornitura di informazioni sugli alimenti: ovvero ancora à la recherche de l'anneau' (2015) 2 Diritto comunitario e degli scambi internazionali 2013.

25 There is reason to believe that the designation "salame" is the typical example of a "traditional name" ("denominazione legale tradizionale" in the original version) devoted to the products so defined in the Decreto del Ministero delle attività produttive 21 settembre 2005, Disciplina della produzione e della vendita di taluni prodotti di salumeria, n. 231/2005. Other examples concern tomato sauce ("passata di pomodoro") according to the Decreto del Ministero delle attività produttive 23 settembre 2005 n. 232/2005 - Definizione di passata di pomodoro, and some products baked in the oven, mentioned in the Decreto del Ministero delle attività produttive 22 luglio 2005, n. 177/2005, Disciplina della produzione e della vendita di taluni prodotti dolciari da forno.

26 According to Art 2, para. 2, lett p), Regulation (EU) 1169/2011, ““descriptive name' means a name providing a description of the food, and if necessary of its use, which is sufficiently clear to enable consumers to know its true nature and distinguish it from other products with which it might be confused".

27 Council Directive 79/112/EEC of 18 December 1978 on the approximation of the laws of the Member States relating to the labelling, presentation and advertising of foodstuffs for sale to the ultimate consumer.

28 Art 2, para. 2, lett $\mathrm{n}$ ) provides that "'legal name' means the name of a food prescribed in the Union provisions applicable to it or, in the absence of such Union provisions, the name provided for in the laws, regulations and administrative provisions applicable in the Member State in which the food is sold to the final consumer or to mass caterers".

29 Art 2, para. 2, lett. o): “"customary name' means a name which is accepted as the name of the food by consumers in the Member State in which that food is sold, without that name needing further explanation". 
expectations of an average consumer who is reasonably well informed and reasonably observant and circumspect". 30

The legal definition of "vegan product", asked for explicitly by numerous scholars, ${ }^{31}$ seems indeed far from being the key to the solution, or at least not the only one. The food law regulatory framework - mainly made up of Article 1 Regulation (EC) 178/2002 and Article 7 Regulation (EU) 1169/2011 - as well as the rules on unfair competition, is actually sufficient to strike a balance amongst the interests at stake. In particular, it serves the purpose - if appropriately enforced at national level - of providing the consumer with fair and understandable information.

Amongst the elements to take into consideration in order to evaluate the deceptive nature of a label, an important role is played by the duration of use of a certain designation. On the contrary, good faith of the producer or the seller, as a "subjective element", cannot impact upon the ("objective") deceptive nature of the label. More generally, the EU legislature in 2011 seems to have focused on the aspect of labelling of food products in which nutritional, physical, chemical and organoleptic features are easily identifiable. The same need is now felt for "vegan products". This is why specific provisions are laid down on designations and indications relating to them (Article 17, para 5 and Annex VI, part A, para $4^{32}$ Regulation (EU) 1169/2011). More generally - as regards "fair information practices" - Article 7, para 1, let d) provides that food information shall not be misleading, "by suggesting, by means of the appearance, the description or pictorial representations, the presence of a particular food or an ingredient, while in reality a component naturally present or an ingredient normally used in that food has been substituted with a different component or a different ingredient".

In the light of the above, it can be concluded that the TofuTown decision undoubtedly contributes some innovative elements, but also discloses some of the contradictions of the regulatory framework in force. In fact, on the one hand, permission is given to the food business operators to make autonomous marketing choices, although with the limits spelled out above; on the other hand, this freedom is limited to some market sectors only, justifying this stance by virtue of an apodictic call to consumer protection, even when such protection is not needed at all.

\footnotetext{
30 Case C-220/98 Estée Lauder Cosmetics GmbH \& Co OHG v Lancaster Group GmbH [2000] ECR I-00117, para. 27; Case C-210/96 Gut Springenheide and Tusky [1998] ECR I-4657, para. 31; Case C-470/93 Verein gegen Unwesen in Handel und Gewerbe Köln eV v Mars GmbH [1995] ECR I-01923, para. 24.

31 T Strecker, 'What is Vegetarian?' (2016) 1 European Food and Feed Law Review 21.

32 This provision provides that "the name of the food shall include or be accompanied by particulars as to the physical condition of the food or the specific treatment which it has undergone (for example, powdered, refrozen, freeze-dried, quick-frozen, concentrated, smoked) in all cases where omission of such information could mislead the purchaser".
} 